\title{
Tax Relieves: Costs of Their Application in Taxation and Issues of the Efficiency Evaluation
}

\author{
Khaibat Magomedtagirovna Musaeva ${ }^{1}$, Basir Khabibovich Aliev ${ }^{1}$, Magomed Magomedovich Suleymanov ${ }^{1} \&$ \\ Tatiana Olegovna Dyukina ${ }^{2}$ \\ ${ }^{1}$ The FSBEU HPE "Dagestan State University", Makhachkala, the Republic of Dagestan, Russian Federation \\ ${ }^{2}$ The Federal State Budgetary Educational Institution of Higher Professional Education "Saint-Petersburg State \\ University", Saint Petersburg, Russian Federation \\ Correspondence: Khaibat Magomedtagirovna Musaeva, The FSBEU HPE "Dagestan State University", \\ Makhachkala, the Republic of Dagestan, 367025, Russian Federation. E-mail: Xaibat27@rambler.ru
}

Received: October 26, 2014 Accepted: December 13, 2014 Online Published: February 12, 2015

doi:10.5539/ass.v11n5p333 URL: http://dx.doi.org/10.5539/ass.v11n5p333

\begin{abstract}
The main objective of this work was to develop a set of scientific and practical recommendations aimed at improving the efficiency of preferential tax treatment based on the analysis of the costs of tax relieves, their types, and their performance evaluation. Direct and indirect costs of tax relieves granted by the World Bank were analyzed within the research. Based on the analysis of legal acts that were in effect in 1990-2000, the specific features and forms of tax relieves used in the Russian Federation were identified. The article shows the necessity of expanded understanding of the tax relieves based on their actual manifestations in various forms, and, based on this, extension of the efficiency evaluation object in the circumstances of the Russian Federation. The article formulates the conclusion about the need to transform the tax relieves in order to strengthen their stimulating effect on the economy development and achievement of the economic benefit and enhancement of the social return. The regulatory-legislative, methodological, and organizational problems of evaluating the efficiency of tax advantages at the regional level (using the materials of the Republic of Dagestan) were revealed, and also a set of recommendations to address them was provided."
\end{abstract}

Keywords: tax relief, costs of tax relieves, advantages, efficiency (fiscal, budgetary, economic, and social), the Russian Federation, the Republic of Dagestan

\section{Introduction}

Tax relieves are one of the main and mobile tools of fiscal regulation of social and economic development. The potential of their use in regulation of economic and social sphere is many-sided. Tax relieves are considerable economic benefits granted by the state and local government to certain economic entities and individuals for the purpose of investment attraction in priority industries or regions, and also for the purpose of social support of certain citizens. Tax relieves can both have the economic and social effect and cause considerable costs. At that, the effect of granting them is not always adequate to budget losses. Certain states benefit from the growth of investments as a result of tax relieves granting, while others fail to attract expected investments, and also suffer budget losses. The main reason of such state of affairs is that costs exceed the expected benefits (effects). This predetermines the urgency of their study. The performance indicators of evaluation of the tax relieves efficiency, the costs of their application and the directions of their reduction were studied in the works by such foreign scientists, as: D. Bondolino (2007), A. Klemm (2009), V. P. Vishnevsky (2006), A. Easson, E. Zolt (2002), Yu. B. Ivanov (2009), S. James (2009), J. P. Morriset, \& N. Pirnia (1999), H. Zee (2002).

Among the Russian scientists engaged in such issues, we can mark the studies of D. B. Volkov (2011), I. V. Gorsky (2014), A. P. Kiriyenko (2014), I. A. Mayburov (2012), V. G. Panskiy (2012), E. N. Orlova (2013), T. A. Malinin (2010), M. R. Pinskaya (2014), N. A. Solovyev (2012). Despite the intensive research performed by the Russian scientists, we have to admit that the main contribution to the study of the problem of costs related to granting tax relieves and of their performance was made by foreign economists. 


\section{Methodology}

The article suggests revised methodology of evaluation of the tax relieves' efficiency adequate to the conditions of relieves granting in the Russian Federation. The issues of functioning of tax relieves are closely connected with the problem of enhancement of the methodology of their efficiency evaluation. In that case, when the relief has no social return or it is economically inefficient, such relief cannot fully perform its role as the most mobile tool of fiscal regulation. Besides, inefficient tax relieves result not only in direct shortfall in budget revenues, but also to such phenomena as decrease in competitiveness of goods (works, services) and in market motivation of economic entities, which do not use tax relieves; to slowdown of the rates of economic growth, to strengthening of social inequality and tensions in the society, etc. Monitoring of the stimulating mechanisms' efficiency is necessary for optimization of the effective tax relieves, and this is one of the important tasks designated in the Basic Concepts of the Tax Policy of the Russian Federation (BCTP) for 2013-2015 and then transferred into the BCTP for 2014-2016.

The efficiency evaluation, as a rule, consists in comparison of the result of a certain action with the costs required for its implementation. However, Russia does not have any uniform methodology of evaluation of the efficiency of tax relieves. In practice, the indexes of the budgetary and social efficiency and in some cases the index of cost efficiency of tax relieves are applied. Beside the listed indexes, I. A. Mayburov suggested to estimate also the ratio of fiscal efficiency, but at the same time to use the index of budgetary efficiency as the «finite criteria index, by the positive value of which the judgment about efficiency of a corresponding relief will be made" (Mayburov et al., 2013).

In the current circumstances, many Russian regions have legal acts regulating the order of evaluation of the efficiency of tax relieves (the evaluation of efficiency is of fragmentary nature at the federal level and at the level of municipalities). The experience of the Orel region is remarkable, as it adopted the law dated 30.06.2009 \#923-OZ "On evaluation of fiscal, social, and economic efficiency of tax relieves granted to certain categories of taxpayers." In the practice of the Orel region both the budgetary (tax relieves encourage increase in revenues or cost optimization of the budget) and economic (tax relieves promote positive dynamics of indexes of financial and economic activity of taxpayers) criteria, and the criterion of social efficiency (contribution of the tax relief to the formation of favorable living conditions for the population) of evaluation of tax relieves (Solovyev, 2012). The said law states that following the results of evaluation of the tax relieves efficiency, the authorized agency prepares a proposal for extension or cancellation of a particular tax relief. The adoption of such a decision following the results of evaluation of the efficiency of incentive mechanisms is recommended by the BCTP for 2013-2015.

According to the author, it is necessary to use the results of monitoring the efficiency of tax relieves for taking the decision not only to cancel or retain the relieves, but also to change the conditions of their application, which will strengthen the stimulating effect of the preferential tax treatment. The positive experience of some regions of the Russian Federation should be distributed in other federation subjects and municipalities, as well as at the federal level. In this case, it is advisable to assess the efficiency of not only the newly introduced relieves, but also of the effective ones.

For comprehensive evaluation of the efficiency of tax relieves, it is obviously necessary to calculate the parameters of the budgetary as well as economic and social efficiency. However, for a number of organizations of public, social, and cultural importance at the regional and local levels, there is no need for calculating the budget efficiency of tax relieves for the purpose of their cancellation. These organizations in particular may include: public organizations of disabled people; homeowners' associations; professional rescue services and forces; control bodies and subdivisions of the State Fire Service of EMERCOM of Russia in the subjects of the Russian Federation; organizations with taxable items recognized historical and cultural monuments, etc. The efficiency ratio of tax relieves granted to the above economic agents will always be less than one (where the normal value of Keff> 1). However, in order to determine the total amount of the shortfall in budget income from preferential tax treatment, monitoring of all relieves is required, including those provided to the above organizations.

In the Republic of Dagestan, the Government Act "On the estimation of the efficiency of fiscal and social submitted tax relieves provided by the legislation of the Republic of Dagestan" dated 25.06.2008 \# 207 was adopted. In accordance with the mentioned Act, the region assigned the responsibility for assessment of the efficiency of tax relieves established by regional law, to sectoral executive authorities. The Ministry of Economy of the Republic of Dagestan coordinates the work in this direction and prepares a summary report based on the materials submitted by sectoral executive authorities. The effect of the tax relieves granted at the federal level is 
virtually not calculated in the Republic of Dagestan (except for the quantitative loss of the budget by certain types of preferences calculated by the Office of the Federal Tax Service of the Russian Federation in the Republic of Dagestan and reflected in the Tax Certificate of the region). This is despite the fact that, as the survey showed, over $70 \%$ of the shortfall in tax revenues comes from the tax relieves established by federal law. In general, the losses of the national budget of the Republic of Dagestan in connection with the provision of tax relieves in recent years tend to increase. Thus, according to the Office of the Federal Tax Service of the Russian Federation in the Republic of Dagestan, the shortfall in revenues of the republican budget of the Republic of Dagestan due to provision of tax relieves in 2013, if compared to 2012, increased by $13.9 \%$, including the increase by $18.6 \%$ caused by the relieves granted in accordance with the Tax Code of the Russian Federation, and the decrease by $26.5 \%$ caused by the relieves granted in accordance with the regulations of the Republic of Dagestan. In this situation, it is necessary to calculate the budgetary losses caused not only by relieves granted by the legal acts of subjects of the Russian Federation, but also by those granted by federal law.

\section{Results}

Our research and analysis of the results of studies of famous specialists allow allocating direct and indirect costs of tax relieves. According to the World Bank experts, the direct costs include:

1. the revenue costs;

2. the resource allocation costs;

3. the enforcement and compliance costs;

4. the costs associated with corruption and lack of transparency.

The Government of the Republic of Dagestan adopted Decree No. 207 dated 25.06.2008 "On Assessment of the Budgetary and Social Effectiveness of the Tax Reliefs Provided in Accordance with the Legislation of the Republic of Dagestan". In accordance with the said Decree, assessment of the effectiveness of the reliefs provided by the regional legislation is assigned to the sectorial executive authorities. The Ministry of Economy of the Republic of Dagestan provides coordination of this work and prepares a consolidated report based on the materials provided by sectoral executive authorities. The effect of the tax reliefs provided by the federal legislation is virtually not calculated (except for the quantitative losses of the budget by certain preferences calculated by the Department of the Federal Tax Service of the Russian Federation in the Republic of Dagestan and registered in the Tax Report Form of the region). At that, as shown by the research, almost $90 \%$ of tax losses in the region are due to the tax reliefs provided by the federal legislation. Totally, the losses of the regional budget of the Republic of Dagestan tend to grow. At the same time, during the 2010-2011 period, the growth rate of the losses of the budget of the Republic of Dagestan due to the provision of tax reliefs has been far ahead of the tax revenues growth rate (Table 1). The calculations according to the Department of the Federal Tax Service of the Russian Federation in the Republic of Dagestan evidence that the lost revenues of the republic's budget due to the provision of tax reliefs increased in 2013 by $157.8 \%$, compared to 2010, including the increase of the losses due to the tax reliefs provided by the Tax Code of the Russian Federation by $163.1 \%$ (Table 1). In this situation, the calculation of the budget losses due to tax reliefs provided by the federal legislation should be of first priority. In 2013, compared to 2012, the Republic of Dagestan showed decrease in the republic's budget losses caused by the preferential taxation. This decrease was determined by cancelling a number of tax reliefs provided locally, particularly, the tax reliefs for the land use tax, cancelled since 01.01 .2013 for organizations and citizens, such as public authorities engaged in control over land use; land for distant-pasture cattle tending, transferred for reclamation in accordance with the established procedure, as well as the land plots newly developed for terrace agriculture for the period of 5 years; citizens who organized peasant farms for the first time on the wasteland for the period of 10 years, starting from the time when they were given the land plots. This approach is generally in line with the concept of the Ministry of Finance of the Russian Federation, which assumes cancelling any reliefs during 2-3 years. However, the reliefs cancelling without assessing their budgetary, economic, and social effectiveness is not reasonable, as it can implicitly lead to more negative consequences in the economy, such as winding-up of enterprises, unemployment growth, growth of prices for products, exodus of capital, etc., i.e. actual ignoring of the regulatory function of taxes.

Calculated based on: the Tax Report Form of the Republic of Dagestan, analytical memorandums regarding receipt of tax payments, tax indebtedness, and activity of the Department of the Federal Tax Service of the Russian Federation in the Republic of Dagestan during 2010-2013; official reporting of the Department of the Federal Tax Service of the Russian Federation in the Republic of Dagestan, website: www.r05.nalog.ru.

Analysis of the results of evaluating the efficiency of tax relieves in the Republic of Dagestan during the period of 2010-2013 evidences existence of multiple problems of both legal regulation and of executive and organizational nature. There are inconsistencies and contradictions in the effective legal acts of the Republic of 
Dagestan governing calculation of the efficiency of tax relieves. Thus, in accordance with the Law of the Republic of Dagestan dated 07.04.2009 \#22 "On evaluation of the socioeconomic efficiency of tax relieves granted to certain categories of taxpayers, the tax relief has positive fiscal efficiency if the sum of the actual (planned) tax revenues to the national budget of the Republic of Dagestan due to granting the tax relieves is greater than or equal to the amount of the granted (planned for granting) tax relieves. However, according to the order of evaluation of the efficiency of tax relieves provided by the Order of the Government of the Republic of Dagestan dated 25.06.2008 \#207-A, the relieves can be provided (kept effective) if the value of the budgetary efficiency ratio is greater than one. In order to bring the Order of the Government of the Republic of Dagestan dated 25.06.2008 \#207-A in accordance with the Law of the Republic of Dagestan dated 07.04.2009 \#22, it is necessary to specify the conditions for recognition of budgetary efficiency of a relief - if the value of the budgetary efficiency ratio is greater than or equal to one (Musaeva, 2014).

Table 1. Comparative characteristic of the growth (decrease) rate of tax revenues and lost revenues of the republican budget of the Republic of Dagestan due to provision of tax reliefs for 2010-2013 (million rubles, \%)

\begin{tabular}{|c|c|c|c|c|c|c|c|c|c|}
\hline & 2010 & 2011 & 2012 & 2013 & $\begin{array}{l}\text { Growth } \\
\text { Rate } \\
2011\end{array}$ & $\begin{array}{l}\text { Growth } \\
\text { Rate } \\
\text { 2012/ }\end{array}$ & $\begin{array}{l}\text { Growth } \\
\text { Rate } \\
2012 /\end{array}$ & $\begin{array}{l}\text { Growth } \\
\text { Rate } \\
2013 /\end{array}$ & $\begin{array}{c}\text { Growth } \\
\text { Rate } \\
2013 /\end{array}$ \\
\hline & & & & & $/ 2010$ & 2010 & 2011 & 2012 & 2010 \\
\hline 1. Tax revenues & $11,456.2$ & $13,485.4$ & $16,669.1$ & $19,234.3$ & 117.7 & 136.8 & 116.2 & 115.1 & 167.9 \\
\hline $\begin{array}{l}\text { 2. Budget losses due to } \\
\text { provision of tax reliefs, } \\
\text { including: }\end{array}$ & 890.9 & $1,212.7$ & $1,381.5$ & 14,060 & 136.1 & 155.1 & 113.9 & 101.8 & 157.8 \\
\hline $\begin{array}{l}\text { - the reliefs provided by } \\
\text { the Tax Code of the } \\
\text { Russian Federation }\end{array}$ & 809.3 & $1,088.5$ & $1,290.5$ & $1,320.1$ & 134.5 & 159.5 & 118.6 & 102.3 & 163.1 \\
\hline $\begin{array}{c}\text { - the reliefs provided by } \\
\text { the regulatory documents } \\
\text { of the Republic of } \\
\text { Dagestan }\end{array}$ & 81.8 & 123.8 & 91.0 & 85.7 & 151.4 & 111.3 & 73.5 & 94.2 & 104.7 \\
\hline
\end{tabular}

*Except for the lost taxes of the budget due to the provision of the tax deductions for the individual income tax

Analysis of application of tax preferences in the Republic of Dagestan shows that in some cases, the organizations' performance before and after being granted relieves is the same. There are cases of wrong calculation of the efficiency ratio of tax relieves. For example, the Dagestan Investment Company issued an opinion to the Ministry of Economy of the Republic of Dagestan on the budget efficiency of the tax relieves provided to four enterprises implementing investment projects in the region, which were recognized as a priority. However, according to the Ministry of Economy of the Republic of Dagestan, "the high values of the tax relieves' efficiency ratios (3.4-3.5), which do not correspond to the gain in revenues and shortfall in revenues the republican budget the Republic of Dagestan, are doubtful."

Calculation of the efficiency of tax relieves in many regions of Russia, including the Republic of Dagestan, is performed for the tax period or the period of the tax relief validity. The tax period for the majority of taxes is a calendar year. However, the negative performance indicators over the given period should not be grounds for its cancellation. Positive efficiency of tax relieves cannot be reached immediately. The effect of the relieves will manifest itself after a longer period. For example, in international practice, the period between taking investment decisions and financing capital investments by corporations is 5 years.

In addition, the presence of a negative value of a certain indicator of the efficiency of a relief should not be the ground for its cancellation or suspension. In this context, comprehensive and systematic approach is needed. Thus, for example, the shortfall in revenues of the republican budget the Republic of Dagestan for 2011 caused by provision of relieves to the CJSC "Sh. Aliyev" amounted to $1,821.3$ thousand rubles. The ratio of budgetary efficiency of tax relieves was equal to 0.3 (normal Cef $>1$ ). However, reduction of arrears from 1,394.0 thousand rubles to 568.0 thousand rubles was achieved for the analyzed economic agent, the average salary rose 
by $107 \%, 12$ new jobs were created, which, in principle, while this trend remains over time, evidences the usefulness of the preferential tax treatment.

The executive authorities of the Republic of Dagestan when calculating the tax relieves efficiency ratios make regular mistakes and inaccuracies. To avoid errors and mistakes in the process of drawing conclusions on the evaluation of the tax relieves' efficiency, the executive authorities should verify the accuracy of the payments received from taxpayers. It is necessary to reconcile them with the data reflected in the forms of accounts. It should be noted that such factors as the lack of official statistics of sufficient information discredits the reliability of estimates of performance indicators of tax relieves. In the process of calculating the efficiency of relieves for regional and local taxes, the main source of information is the data coming directly from taxpayers. The tax returns and calculations of taxpayers should contain not only the data on the relieves granted by the Tax Code of the Russian Federation in the narrow sense, but also, from the viewpoint of extended interpretation, on all examined types of relieves (exemption of individual objects of taxation, tax cuts, tax deductions, etc.).

For certain federal taxes, which are source of generation of revenues for regional and local budgets (PIT, CPT), statistical tax reporting allows to quantify the shortfall in budget revenues caused by the granting of tax relieves. Thus, for example, the data of the "Report on the tax base and structure of charges on income of individuals, withholding tax agents" (5NDFL), allow us to estimate the budget losses from tax deductions. Quantitative assessment of the budget losses caused by granting tax relieves on the personal income tax is calculated by the tax authorities and they reflect the results of the calculations in the Tax Certificate in the section "Relieves on individually administered income". However, the tax authorities assess only the quantitative loss as a total, without calculating the economic, budgetary, and social efficiency. Calculation of the efficiency of tax relieves (economic, fiscal, and social) is performed by the relevant executive authorities of the Republic of Dagestan only for the relieves granted by the regional and local legislation that does not allow for complete characterization of the efficiency of the preferential tax treatment. In this case, the responsibility of the Ministry of Economy does not include compilation of data on the relieves provided by federal law.

For completeness of evaluation at calculation of the ratio of budget efficiency of tax relieves, it is necessary to take into account the increase (decrease) in total tax revenues, including their types, and not only in the revenues to which the relieves are applied. When relieves are granted by the federal legislation, it is appropriate to perform calculation of changes in tax revenues for both the federal taxes and the state and local ones. This calculation is necessary for monitoring and further analysis, as proper provision of relieves on certain taxes can also have positive effect on other tax payments.

In confirmation of the above findings, we note that, for example, if one provides relief on the corporate profit tax with regard to the amounts allocated for the creation of additional jobs, the shortfall in budget revenues from this tax may be offset in this case by:

- Reduction in government spending for unemployment allowances in connection with creation of additional jobs;

- Increase in revenues from indirect taxes and non-tax revenues of the federal budget (the VAT, excise, and customs duties) by broadening the tax base and increasing consumption of goods and services by the population (it is assumed that the marginal propensity to consumption of the population is about $3 / 4$, and the marginal propensity to saving $-1 / 4$ );

- Increase in revenues from the personal income tax, due to the expansion of the tax base caused by the growing number of people employed;

- Increase in payments from insurance premiums to non-budgetary social funds.

\section{Discussion}

In the USA, during the period of 1983-2011, the tax expenses (tax reliefs provided to taxpayers as an alternative to budget expenses) fluctuated between 5.6\% and 9\% of the GDP (Burman \& Phaur, 2011).

Let us consider the costs of tax relieves in detail.

Direct costs associated with the shortfall in revenues. Tax relieves do not affect adversely on revenues when investments that are subject to the exemptions are additional to those that would be implemented in the absence of the relieves. The shortfall in budget revenues as a result of tax relieves may occur due to the influence of two main reasons:

- The foregone revenue from projects that would have been made even in the absence of tax relieves (redundancy); 
- $\quad$ The misuse or incorrect use of the relieves by economic agents of motion of the revenues from taxable companies to companies enjoying a favorable tax regime due to the relieves.

Formal solution is to grant tax relieves only to those investors who otherwise would not invest. However, it is difficult to determine which specific projects can be implemented solely because of a tax relief. It is equally difficult for the economy as a whole to assess the level of investment in the presence of preferential tax treatment or without it. Additional costs of revenue loss due to the use of tax relieves arise from the erosion of the revenue base at the taxpayers' expense, using preferential treatment for the purpose of tax evasion, tax planning, or conducting inappropriate activities.

Costs of resource allocation. Successful application of tax relieves contributes to additional investments in sectors, regions, or countries that would not be implemented without these relieves. Sometimes, the cause of investments is the correction of market failures. At the same time, not completely efficient preferential policy may result in uneven distribution of resources, with some activities obtaining overinvestment, and others lacking the investments. Determination of the effect of tax relieves on the markets of developed countries is a challenge. But it is even harder to figure out is whether the use of tax relieves for the more imperfect markets of developing countries can make these markets more competitive (Klemm et al., 2009).

Costs of enforcement and compliance with the legislation. These costs are associated with the primary relieves, supervision of compliance with legislation (relating to the control of the costs of tax authorities) and the establishment of new preferential rules. In addition, this may include the costs of taxpayers related to regulatory compliance. At the same time, the more complex the preferential tax treatment is, the higher the costs of enforcement and compliance are (Malinin, 2010).

Costs associated with corruption and lack of transparency. With "manual" control over relieves granting, the transparency and the impersonality of their obtaining reduce, and the opportunities of corruption among officials increase (Easson \& Zolt, 2002).

Costs of tax relieves are difficult to estimate and calculate. Relieves successful in one country or region may be inefficient in other places. In many countries, preferential taxation regimes vary from public tax holidays to narrowly focused types of relieves. Costs evaluation typically provides for preparation of reports to assess the impact of certain tax relieves (existing and supposed) on the level of revenues (Pinskaya et al., 2014).

The costs of using tax relieves are large-scale and not limited to immediate shortfall in revenues. They also include distortions in the economy (indirect costs) as a result of preferential treatment for investment, the administrative costs of implementing and prevention of illegal use of the relieves, and the social costs of the rent-seeking behavior, including possible increase in the level of corruption. Indirect shortfall in revenues can occur under the influence of taxes on investment, which have come solely as a result of tax relieves introduction and have superseded other investments that are subject to a higher tax. On the other hand, the growth of aggregate investments and economic activity can ensure the gain in income due to additional payroll taxes or taxes on inputs. In detail, the indirect costs of tax relieves include: distortions caused by stimulation of new investments that adversely influence on the existing investments; shortfall in revenues due to illegal activities, such as falsification of information by investors in order to obtain relieves, or indirect shortfall in revenues of investors that formally do not work in the privileged mode, but illegally use companies in their activity, which enjoy the relieves (for example, at purchasing goods); costs for the authorities responsible for tax relieves administration. Indirect costs are difficult to quantify, though they may substantially exceed the direct financial costs of preferential tax treatment (Ivanov et al., 2014).

It should be noted that in the Russian Federation, the prospects of tax relieves, both in terms of socioeconomic essence and costs of their use, and from the point of view of efficiency improvement are under-researched.

The Federal Law of the Russian Federation "On the principles of the Russian tax system" did not contain any regulatory definition of a tax relief. The Tax Code of the Russian Federation just formally eliminated the gap. Despite the nearly 15-year period of its study, this area of scientific - practical research remains the least researched and discussed. This fact is recognized by famous modern scientists in taxation. Thus, according to V. G. Panskov "Neither the tax laws, nor scientific papers provide clear definition of what a "tax relief" is; there is no scientifically-grounded criteria and guidelines for calculating the efficiency of their application. There is no clarity as to how and who is to monitor the efficiency of the granted relieves and other preferences" (Panskov, 2012).

The definition of a tax relief formulated in the Tax Code of the Russian Federation (Article 56), determines its largely generalized understanding of it, as advantage provided to certain categories of taxpayers compared to 
others. At that, the results of such advantage may be manifested as a decrease in the tax burden (tax amount) and facilitation of compliance with tax obligations (for example, lesser frequency of tax returns).

Most definitions given in scientific and educational papers are different from the definition of the tax relief as set out in the Tax Code only by their form but not by their content. For example, N. A. Solovyev treats the essence of the definitions of "tax benefit" as "advantages granted by the legislation on taxes and levies granted to certain categories of taxpayers compared to other taxpayers, providing for the possibility not to pay a tax or pay it at a lesser rate" (Solovyev, 2012).

Malko A. V. believes that a tax relief should be understood as a legitimate relief to the subject, allowing it to meet its interests better, and is expressed as both provision of additional specific rights (advantages), and liberation of it from duties" (Malko, 2006). However, in fact, under current law, the tax relief provides for full or partial exemption from payment of the tax, but not from the tax obligation. In the process of the liberation of the taxpayer from payment of the tax, the taxpayer remains liable for accounting and reporting on virtually all taxes. D.B. Volkov treats tax relieves as separate type of tax incentives, which differs from the preferences by the voluntariness of their application by taxpayers (Volkov, 2011). Formulated definition, in the author's opinion, does not allow revealing fully the socioeconomic and legal nature of tax relieves.

According to the author, the best description of the definition of relieves is provided by A. I. Mayburov who believed that "a tax relief is an optional element that characterizes the providing by the tax laws of certain categories of taxpayers (payers) with exceptional advantages, including the ability not to pay a tax (a fee) or pay it at a smaller rate, as well as other mitigation of the tax burden for the taxpayer" (Mayburov \& Ivanov, 2012).

Analysis of the current Russian legislation on taxes and duties evidences that a tax relief can be established only by the tax legislation and only for certain categories of taxpayers. At that, a tax relief must provide special procedure for calculation and payment of the tax and offer particular advantage to certain categories of taxpayers compared to others, while all other taxpayers are subject to the general liability with regard to this tax. Further, a tax relief is a right, but not an obligation of the taxpayer. A taxpayer may waive the statutory rights granted to it by a tax relief or suspend the use of the right for one or more tax periods (Malko, 2006).

However, the Tax Code of the Russian Federation regulates neither the procedure of waiver nor the procedure of suspension of usage of tax relieves clearly, which hinders full exercise of this right by a subject of taxation. In terms of the law, waiver of tax relieves and suspension of their use are different phenomena. The right not to use (suspend) a tax relief does not mean that the entity by not using its advantage waives the advantage forever and will not be entitled to recover its right in the future. Waiver of tax relieves provides for the decision of an economic agent never to use the advantage granted to it by the government. At the same time, the suspension of usage of a tax relief for one or more periods implies the same waiver, but not a final one, just a temporary waiver allowing the taxpayer to enjoy the advantage granted to it by the law in the future.

The study of the Russian law allows separating the following forms of tax relieves used in the Russian Federation:

- Exemption of certain categories of taxpayers from payment of the tax. For example, in accordance with Article 145 of the Tax Code of the Russian Federation, companies and individual entrepreneurs are entitled to exemption from the duties of calculation and payment of the VAT, provided during the previous three consecutive calendar months, the amount of revenue from sale of goods (works, services) of these entities and individuals did not exceed two million rubles without VAT totally.

- Release of individual objects from taxation (tax exemptions). For example, Article 217 of the Tax Code of the Russian Federation provides a wide range of revenues that are not subject to personal income tax (government allowances, pensions, scholarships, compensation payments, grants, lump-sum payments, etc.).

- Lowering the tax rate. In the Russian Federation, the basics VAT rate is $18 \%$. However, in some cases stipulated by Article 164 of the Tax Code of the Russian Federation, the tax is paid at the reduced rate of $10 \%$. The basic personal income tax rate equals to $13 \%$, but for the income of individuals who are tax residents of the Russian Federation the rate is reduced to 9\% (Article 224 of the Tax Code of the Russian Federation).

- Tax deductions. This relief assumes exception of certain amounts from the tax base (available for such taxes as the VAT, the personal income tax, and excise taxes).

- Change in the frequency of payment of the tax (deferrals, payment in installments, and an investment tax credit). 
The above forms of tax relieves are separated by the author based on the analysis of legislation of both the 1990s and the 2000s. It should be noted that the same legal phenomena in terms of the legal status were differently formulated by the legislator at different stages of development of the Russian tax system. For example, prior to the enactment of the Tax Code of the Russian Federation, the release of part of the profit allocated to repay the losses of the previous years was called tax relieves. Chapter 25 of the Tax Code of the Russian Federation also contains a similar provision. However, under the current legislation in effect since 1.01.2002 relieves for the corporate profit tax have been completely cancelled. The content of the definition of the tax relief as set out in the first part of the Tax Code is not confirmed in the second part. The second part of the Tax Code of the Russian Federation contains a number of various preferences, which the legislator does not treat as relieves formally, but which in fact are ones. Thus, there is some terminological substitution of some concepts with others, which creates much more opportunities for violations of the tax law and hinders estimating the shortfall in budget revenues caused by provision of various kinds of preferences. In this regard, the author shares the views of A. I. Mayburov about the need for broader understanding of tax relieves (Mayburov \& Ivanov, 2012) based on their actual manifestations in various forms (tax exemptions, tax deductions, tax breaks, etc.).

In view of the above, the author finds it correct to understand tax (fees) relieves as relieves granted to certain categories of taxpayers (payers) in various forms if compared to other taxpayers (payers of fees), which relieves provide the opportunity not to pay the tax (the fee), or pay it at a lesser rate, or facilitate the compliance with the tax duty, provided there are grounds and the entity complies with the conditions as stipulated by the tax legislation.

One of the main problems of improving the tax system of the Russian Federation is the development of the government policy and ensuring its efficiency in the mechanism of provision and implementation of tax relieves. The uncontrolled growth of tax relieves results, on the one hand, in excessive differentiation and prevention of creating "identical" conditions, and, on the other hand, opens the tax loopholes, which in turn increases the pressure on the law-abiding taxpayers. Such conditions on top of the economic impact in the form of the tax base reduction also result in the rise of the opinion in the society that there is a too high level of taxation.

In the tax system, according to the Ministry of Finance, there are about 200 different kinds of relieves and preferences, which tend to increase in recent years. This increases not only the number of relieves provided, but also their total amount (Panskov, 2012). For example, provision of various kinds of preferences for VAT resulted in the $21.7 \%$ growth of the shortfall in federal budget revenues in 2013 compared to 2012, with the amount of the shortfall equal to $1,834.6$ billion rubles, while VAT revenues in the budget increased by just $12.9 \%$. In the Republic of Dagestan, tax deductions for VAT in 2013 increased by $23.9 \%$ compared with 2012 . The VAT subject to recover from the budget according to tax returns increased 1.9 times, where the VAT calculated for payment to the budget grew by just $9.0 \%$ (Musaeva, 2014). Thus, there is anticipating growth of budget losses from the provision of various kinds of preferences if compared to the amounts of the VAT revenues.

As a result of provision of various kinds of relieves, the state does not receive by various estimations between $45 \%$ and $55 \%$ of all tax payments administered by the Federal Tax Service of Russia. Under these circumstances, the search of a reasonable balance of tax relieves and the need to improve their efficiency continue to be the pressing issues. The priority for improvement of the tax system is the elimination of the relieves, which are not efficient in socioeconomic terms, but at the same time provide significant advantages to certain taxpayers as well as opportunities for tax evasion. However, refusal from relieves, as well as the process of introduction of new relieves should be accompanied by their preliminary examination of their use and feasibility. Refusing from tax relieves without any analysis of the causes of their poor efficiency, the state loses leverage over the economy and the social policy, and narrows its capabilities to the framework of the current, mainly fiscal tasks to the detriment of the strategy of the socioeconomic growth.

Transformation of relieves is needed in order to strengthen their stimulating impact on the economy development and achievement of the effect and increasing social returns. Currently, there is no single mechanism of granting relieves in the country, which would define the objectives, priorities, and types of granting relieves, correlated and complementing each other by all types of taxes. The result of this is that the relieves provided for in the mechanism of certain taxes lose their stimulating effect and weaken the overall efficiency of the fiscal policy. Objectives, priorities, and types of granting tax relieves should be more closely aligned with national priorities. Analysis of legislative acts of the Russian Federation shows that out of 200 currently effective tax relieves, only 15 target encouraging investments and innovations (Orlov, 2013). Under these conditions, the existing mechanism of granting tax relieves is hardly consistent with the priorities of the government in the field of stimulation of investment activity of the economy, development, and implementation of innovations. In the situations where the share of high-tech products of Russia is less than $2 \%$ in the international market and 
depreciation of fixed assets is more than $50 \%$, it is necessary to use more efficiently the tools of the government regulation of the economy, including the tax regulation, to strengthen their focus on encouraging companies to invest, create and implement innovative technologies.

One of the main sources of investment resources of companies is profit, which may be increased primarily due to preferential tax treatment. Economists recognized that those are direct taxes, including mainly the corporate profit tax, that have significant potential for the regulatory impact on the pace, scope, and direction of the investment activity. For this tax (despite the abolition of relieves since 01.01.2002), it is currently possible to include the costs accounted for tax purposes, namely the costs for Research and Development, the costs for repair and development of natural resources; and also the possibility of using the multiplying factor (1.5) with the purpose of accelerated accounting of current costs for research and development is provided. However, the advantages of the regulatory nature of the corporate profit tax in the Russian practice of taxation are not fully used. Currently in the Russian Federation, it is reasonably necessary to expand investment tax relieves at the expense of the costs for acquisition and implementation of innovative technologies at taxation of the profit.

The mechanisms of tax relieves in effect in Russia are aimed mainly at supporting development of innovative products. However, it is not enough just to create an innovative product. It must be put into production. The successful solution of the problem of modernization of economy is possible with the creation of conditions for development of the real sector of the economy using innovative ideas and innovative products. At establishing tax relieves aimed at supporting individual sectors and industries of the economy, one should define the goals that must be achieved in the result of their application, record the socioeconomic indexes of the taxpayers' performance (growth of production volumes, additional budget revenues, creation of new jobs, rise of wages, etc..).

It is known that in the circumstances of the current tax law in the Russian Federation, significant budget losses are observed due to unreasonable application of VAT deductions (which are actually tax relieves). First of all, regarding application of the $0 \%$ VAT rate on exports of goods, works, and services. According to official data of the Ministry of Finance of the Russian Federation, almost half of the collected VAT amount is annually returned from the budget to exporters, i.e. in fact it is redistributed to the benefit of the highly profitable industries. In this case, it would be advisable to replace the $0 \%$ VAT rate with exemption of export transactions from paying it (without VAT refund). This approach would allow significant reduction of the interest of economic agents in false export while keeping tax incentives for development of real export of goods, works, and services.

Creation of a unified and dedicated system of granting tax relieves assumes that the mechanism for each tax should be based on the principles common for the whole taxation system. An example of a principle that is not in line with the general principles of taxation (in accordance with Article 3 of the Tax Code of the Russian Federation, it is not allowed to establish different rates depending on the form of ownership) is the relief which assumes exemption from VAT (Article 149 of the Tax Code of the Russian Federation) of operations of sale of goods, works, and services produced and sold only by state unitary enterprises at TB, psychiatric, and neuropsychiatric institutions, institutions of social protection and social rehabilitation of the population.

It is necessary to link the mechanism of providing relieves with the terms of use of the funds released, as well as with the abidance by particularly stipulated conditions. For example, at granting relieves to business entities at the regional and local levels, it is not sufficient to require compliance with one criterion (the type of industry or activity) - it is advisable to perform such specific conditions as reduction of arrears on tax payments to the budget, use of local raw materials in the production process, development of local natural resources, implementation of regional programs, etc. The intended purpose and the conditions for granting relieves should be particularly defined and listed in the decision of the authority, granting the tax relief.

In the current circumstances, more attention is paid to calculations of the tax potential of regions based on their Tax Certificates (the official document, which in a systematic manner provides information of general and special nature, which is needed for evaluation of the tax potential of the region). Tax Certificates may be of practical value if their data are sufficient to reflect the actual tax burden and tax potential of the regions.

Currently, in the Tax Certificate of the subject of the Russian Federation, there is the section "Relieves by individual administered revenues". However, it indicates the amounts of budget losses caused by submission of tax relieves to be credited in full or in part to the regional and local budgets for only two types of tax exemptions: the reduction of the tax rate and the release of individual categories of taxpayers from payment of the tax. For example, the Tax Certificate does not contain information on the losses of the regional and local budgets because of provision of deductions from the personal income tax. In our opinion, the Tax Certificate should contain detailed description of all types of tax relieves, including tax deductions and tax exemptions. Generally, it is 
advisable to introduce a special reporting form specifying all kinds of tax relieves for both federal, regional, and local taxes indicating the amounts of actually used by taxpayers due to the granting of the tax relieves, which would solve the problem of insufficient and fragmented information for more accurate evaluation of the tax relieves efficiency.

\section{Summary}

The performed analysis of the theoretical aspects and the practical experience of application of tax relieves in the Russian Federation and in its individual subjects give reasons to conclude that solution of at least the following correlated tasks is needed for improvement of efficiency of the evaluation of tax relieves in the Russian Federation, in order to optimize them, provided at both the federal, regional, and local levels:

- Legislative assignment of the authority responsible for monitoring the efficiency of tax relieves established by the Tax Code and other federal and regional laws, and by decisions of local governments;

- Formation of new understanding of the definitions of "tax relief" and, based on this, separation of the object of evaluation and monitoring of a tax relief. The object of evaluation of the efficiency of tax relieves should be expanded in practice based on their actual manifestation in the studied forms;

- Revision of the methodology and periodicity of evaluation of efficiency of the tax relieves both existing in the legislation and planned for introduction as well as conditions for granting them;

- Ensuring adequacy of statistical information for correct calculation of the system of the tax relieves' performance indicators. This problem can be solved by improving the work on amendment of the forms and lists of reports of tax authorities, the Tax Certificate of subjects of the Russian Federation, tax returns and calculations of taxpayers, as well as documents provided by the relevant executive authorities.

The need in comprehensive solution of the issues outlined above requires in-depth study of the reduction of tax relieves costs, improvement of efficiency of the preferential tax treatment in the world and in the Russian Federation. It is recommended to specially focus in researches on the issues of improvement of the indexes of the tax relieves efficiency evaluation.

\section{Acknowledgements}

The article and the research were financially supported within the government order \#26.1569.2014 of the Ministry of Education and Science of Russia in the field of scientific activity in the direction of the project "Tax mechanism as a tool of current regulation of interregional socioeconomic differentiation".

\section{References}

Bondolino, D., \& Greenbaum, R. T. (2007). Do Local Tax Incentives Affect Economic Growth? What Mean Impacts Miss in the Analysis of Enterprise Zone Policies. Regional Science and Urban Economics, 37, $121-136$.

Burman, L. E., \& Phaur, M. (2011). Tax expenditures, the size and efficiency of government, and implications of budget reform. National Bureau of Economic Research (p. 36). http://dx.doi.org/10.3386/w17268

Easson, A., \& Zolt, E. M. (2002). Tax Incentives (p. 123). World Bank Institute.

Gorsky, I. V. (2014). About tax regulation, tax reliefs and functions (the historical and methodological aspect). Economics. Taxes. Law. The International Scientific and Practical Magazine, 3, 17-23.

Ivanov, Yu. B. (Ed.). (2009). Taxation: the problems of science and practice (p. 343). Kharkiv: INZHEK.

James, S. (2009). Incentives and Investments: Evidence and Policy Implications (p. 77). Investment Climate Advisor- Services of the World Bank Group. http://dx.doi.org/10.2139/ssrn.2401905

Klemm, A. (2009). Causes, Benefits, and Risks of Business Tax Incentives (p. 34). IMF Working Paper \#WP/09 2. Washington, D.C.: International Monetary Fund. http://dx.doi.org/10.5089/9781451871685.001

Malinin, T. (2010). Evaluation of tax relieves and exemptions: international experience and the Russian practice (p. 330). Moscow: IET.

Malko, A. V., \& Matuzov, N. I. (2006). Relieves, privileges, and immunities in law. The theory of the state and the law (p. 484). Moscow: Yurist.

Mayburov, I. A., Ivanov, Y. B., \& Tarangul, L. L. (Eds.). (2013). Economy of tax reforms: Monograph (p. 227). Irpen, Kiev: Alerta.

Mayburov, I. A., Panskov, V. G., \& Kiriyenko, A. P. (2014). Tax relieves. Theory and Practice (Mayburov, I. A. Ed., p. 490). Ivanov. Moscow: UNITY - DANA. 
Morriset, J. P., \& Pirnia, N. (1999). How Tax Policy and Incentives Affect Foreign Direct Investment: A Review. World Bank Policy Research Working Paper, 2509, 89. http://dx.doi.org/10.1596/1813-9450-2509

Musaeva, Kh. M. (2014). The fiscal performance and ineffective relieves: the Dagestan experience. Finansy, 6 , 29-30.

Orlova, E. N. (2013). Tax relieves in the Russian Federation: Practical Applications and Methods of evaluating efficiency. In the Proceedings of the 5th Ukrainian-Russian Symposium: Theory and Practice of Tax Reform. Scientific Works of the Scientific Research Financial Institute, Kiev, 2(63), 3.

Panskov, V. G. (2012). Tax relieves: practicability and efficiency. Finansy, 10, 34.

Pinskaya, M. R., Avramov, G. A., \& Alaev A. A. (2014). In I. N Rykov (Ed.), Russian and foreign experience of stimulating private investments: inventory of tax relieves and other support measures (p. 340). Moscow: NIFI.

Solovyev, N. A. (2012). Tax deductions and relieves: the problems of correlations and legislative statement (p. 191). Moscow: Knorus.

The tax system. (2012). In I. A. Mayburova, \& Y. B. Ivanova (Eds.), Methodology of development: monograph (p. 39). Moscow: UNITY DANA.

Vishnevsky, V. P. (Ed.). (2006). Taxation: theories, problems, and solutions (p. 453). Donetsk National Technical University, IEP NASU.

Volkov, D. B. (2011). Types of tax relieves. Finansy, 3, 65.

Zee, H. H., Stotsky, J. G., \& Ley, E. (2002). Tax Incentives for Business Investment: A Primer for Policy Makers in Developing Countrr. World Development, 30(9), 1497-1516. http://dx.doi.org/10.1016/S0305-750X (02)00050-5

\section{Copyrights}

Copyright for this article is retained by the author(s), with first publication rights granted to the journal.

This is an open-access article distributed under the terms and conditions of the Creative Commons Attribution license (http://creativecommons.org/licenses/by/3.0/) 